\title{
Technical Note: A simple method for preparing reference slides of seed
}

\author{
MARIA A. DACAR AND STELLA M. GIANNONI
}

Authors are a research assistant (M.D.) and a researcher (S.M.G.), Biodiversity Research Group (GIB). Instituto Argentino de Investigaciones de las Zonas Aridas IADIZA-CONICET. P.O.Box 507.5500 Mendoza, Argentina.E-mail: giannoni@lab.cricyt.edu.ar.

\begin{abstract}
Microhistological analysis has become the most commonly used and successful method for determining micromammal diets. However, this technique has a number of limitations, particularly when used on fecal samples where identification of some items is difficult. This method underestimates those nearly unrecognizable plant parts in the diet, such as seed, and overestimates easily identifiable parts, such as leaf epidermis. In this note we describe a simple technique that uses a macerating solution of $17.5 \%$ $\mathrm{NaHCO}_{3}$ for preparing reference slides of seeds. Advantages of the proposed method are discussed and compared with Jeffrey's technique.
\end{abstract}

Key Words: microhistological analysis, technique, seed, rodents

Determining animal diets is of great importance to ecological studies (Krebs 1989). The microhistological technique has been used extensively for diet analyses over the last 50 years (Dusi 1949, Neal et al. 1973, Hansen 1975, Merrill 1994, Campos 1997). Microtechnical procedures require the preparation of reference material from plants growing in the study area. To avoid serious errors in identifying diet components, reference materials must be prepared properly (Dusi 1949).

Rodents inhabiting arid regions are mainly omnivorous (Costa 1995). However, most of the information on the diets of desert rodents comes from species of the family Heteromyidae. These diets have been investigated fundamentally by inspection of the contents of cheek pouches (Reynolds 1958) although Reichman (1975) regards such contents as a poor indicator of what an animal eats. Diets of other groups of rodents have been analyzed using the microhistological technique (Meserve 1981, Ojeda et al. 1996, Campos 1997, Castellarini et al. 1998). Because rodent omnivory in arid environments is widespread (Costa 1995), new techniques are needed to increase the accuracy in identifying parts such as stems, seed, roots, etc. (Johansen 1940).

A maceration technique must be used to remove the epidermis of seeds, stems and bark. According to Johansen (1940), all stems can be disassociated into their components by using proper maceration methods. These can also be applied to seeds by treating

Research was partly funded by CONICET Grant PIP No. 4684 PEI No. 388 and Agencia Nacional de Promoción Cientifica y Tecnológica (Pict 03281). Authors wish to thank M. Tognelli, J. Bonshoven and N. Horak for assistance in the English version. We thank C. Borghi for his advice during all stages of the project; R. Ojeda, R. García Gonzalez, D. Gomez, J. Polop, and F. Castellarini for critically reviewing the manuscript; and R. Papú for helping us take the photographs.

Manuscript accepted 26 Aug. 2000.

\section{Resumen}

El análisis microhistológico ha sido el método más utilizado para determinar la dieta de micromamíferos. Sin embargo, esta técnica tiene importantes limitaciones, principalmente cuando se requiere identificar algunas partes duras de las plantas, como semillas y tallos. Por un lado, ésto ha conducido a que se subestimen las partes dificilmente identificables de las plantas, como semillas, y por otro, a la sobrestimación de aquellas partes fácilmente identificables como la epidermis de las hojas. En esta nota describimos una técnica simple para preparar los patrones de referencias de las varias capas que forman las semillas. Éstos son necesarios no sólo para identificar las especies de frutos de las plantas consumidas por los roedores sino también las partes de las semillas. Las ventajas del método propuesto son discutidas y comparadas con el método de Jeffrey.

them as though they were hard woody tissues. Jeffrey's method is one of the most frequently used for preparing reference slides of hard tissues such as seed (Dellafiore and Polop 1994, Castellarini et al. 1998). The purpose of this report is to describe the use of a sodium bicarbonate solution to macerate the seeds and dissolve the middle lamellae that bind the cells together for preparing reference slides for seed identification in rodent diets.

\section{Materials and Methods}

As proposed by Reichman (1975) for heteromyids, the term "seed" will be used to describe any seed or fruit of a plant eaten by rodents. Several hard, tightly bound layers of tegument usually form the external coat of seeds and are very difficult to separate, hindering preparation of reference slides and impeding seed identification in the diets of rodents. The solution to this problem lies in using effective fluids to saturate the seeds' external layers so that they can be separated. We addressed this problem using a macerating solution of $17.5 \% \mathrm{NaHCO}_{3}$ (sodium bicarbonate). The seeds were soaked from 24 to 36 hours, depending on the seed coat thickness. This soaking process softened the hard parts of the seeds and facilitated separation of the different parts under a binocular magnifying glass with the help of tweezers and a scalpel.

Every seed part, including the endosperm and embryo, was scraped, then cleared by soaking in a solution of $50 \%$ sodium hypochlorite (household bleach) for $20 \mathrm{~min}$ and then washed with abundant distilled water. These parts were mounted separately onto slides in a drop of pure glycerin. Cover slips were added 


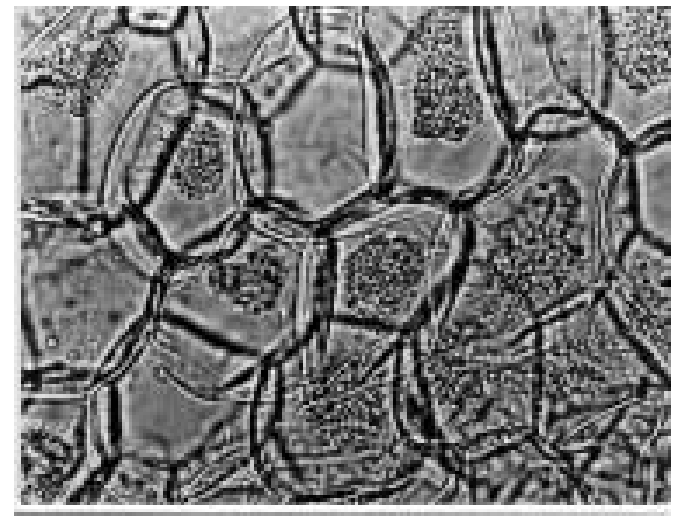

a

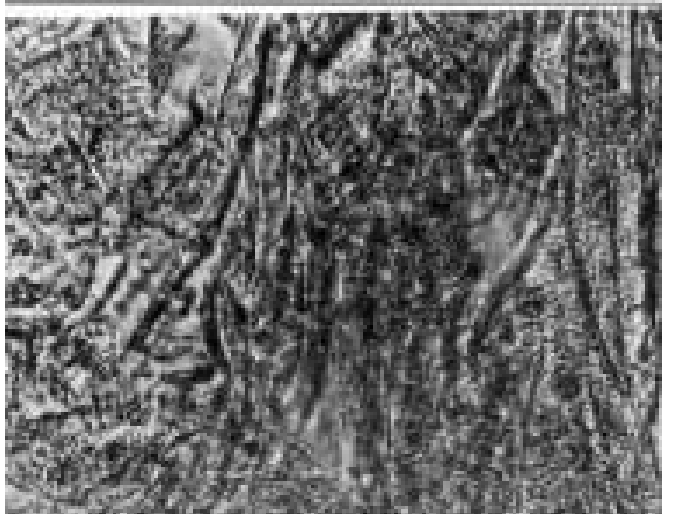

b

Fig. 1. Photomicrographs of reference slides at 400x magnification of the eternal layers of seeds from Larrea divaricata prepared with the sodium bicarbonate method (a) and the Jeffrey's method (b).

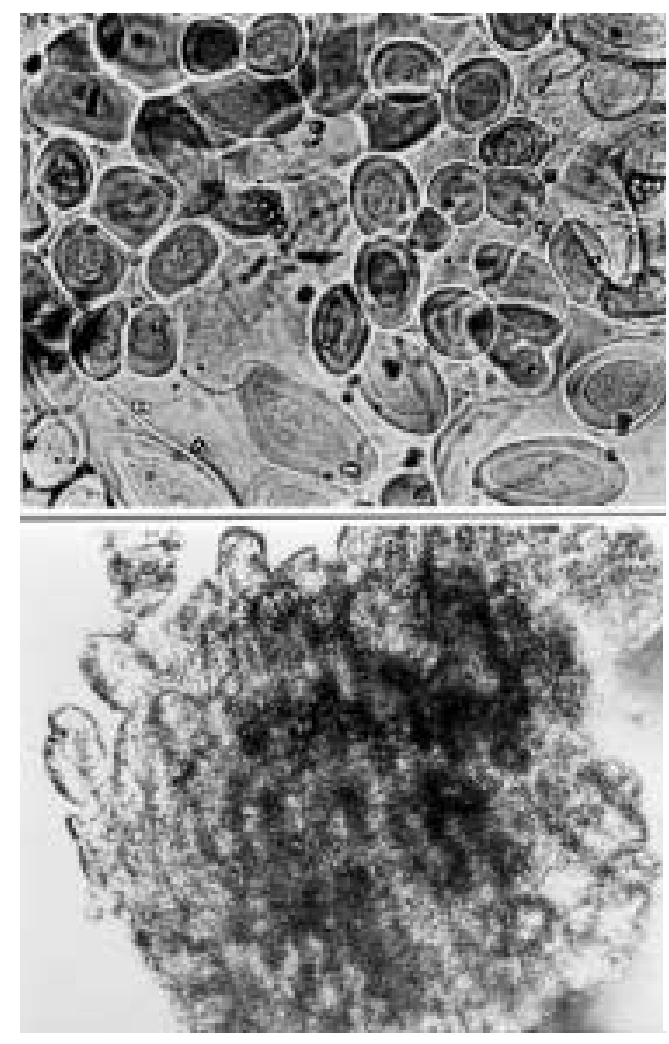

a

b

Fig. 2. Photomicrographs of reference slides at 400x magnification of starch from Prosopis Flexuosa seeds prepared with the sodium bicarbonate method (a) and the Jeffrey's method (b). cautiously and a coating of transparent nail polish was brushed over their margins to seal the mounts.

Reference slides were prepared using both Jeffrey's method and the technique proposed in the present note, in order to compare sharpness obtained. Jeffrey's method (Johansen 1940) is a dissociation technique, and its procedure is as follows: first the material (either fresh or dry) is cut into small slices or slivers about 300 micras thick, boiled and cooled repeatedly until free from air (a suction pump may be used for the same purpose). Then it is macerated in a solution of equal parts of $10 \%$ aqueous nitric acid and $10 \%$ aqueous chromic acid. The time varies according to the material, but cells should begin separating in about 24 hours. A thick glass rod with rounded end may be used to crush the material very gently. If it does not crumble easily, the macerating mixture can be replaced with fresh fluid, and then must be washed thoroughly with water to remove the acids. Finally the material is stained with any suitable basic stain; safranin may be recommended.

We used seeds of 4 shrub species from the Monte desert (Argentina): Bulnesia retama (Gill. Ex Hook.) Griseb., Larrea divaricata Cav., Lycium chilense Miers, and Prosopis flexuosa D.C. Bulnesia retama (Zygophyllacea) has dry dehiscent fruits (capsules), L. divaricata (Zygophyllacea) has schizocarp fruits divided at maturity into 5 hirsute and uniseminate mericarps, L. chilense (Solanaceae) has a pluriseminate suborbicular berry (Peralta and Rossi 1997), and P. flexuosa (Leguminosae) fruit is a modified indehiscent legume with a thin epicarp, a mesocarp which can be either fleshy, sugary or fibrous, and several uniseminate endocarp segments (Burkart 1952). A sample of the feces of Eligmodontia typus Cuvier (Muridae, Rodentia) collected in the field was prepared following the procedure proposed by Williams (1969) to compare the seed coat layers of $L$. chilense with the reference slides. We selected this shrub because it is frequently found in this rodent's diet (Giannoni and Dacar unpublished data). Photomicrographs of the reference slides and of feces were taken with an optic microscope at 400x magnification, except for those epidermal tissues having very long hairs (trichomes) which were photographed at 200x magnification.

\section{Results and Discussion}

Remarkable differences were found in comparing reference slides prepared using the sodium bicarbonate solution method compared with Jeffrey's method. The former technique helps soften the seed coat layers, thus allowing their separation and removal with tweezers, making preparation of reference slides easier. With Jeffrey's method, all seed coat layers are mixed together and preparation of slides is consequently more difficult, as observed in comparing the external layers of Larrea divaricata obtained with both methods (Fig. 1a and 1b). The sodium bicarbonate solution makes it possible to create reference slides of starches from Prospis fleuosa seeds, as shown in Fig. 2a, which we could not achieve with Jeffrey's technique (Fig. 2b). In comparing the photo of Lycium chilense seeds obtained from feces (Fig. 3a) with reference slides of this plant species prepared with both methods (Fig. $3 \mathrm{~b}$ and $3 \mathrm{c}$ ), the sodium bicarbonate maceration technique provided much more recognizable parts of fruits consumed. A comparison of Bulnesia retama seeds, which had trichomes, again showed that 


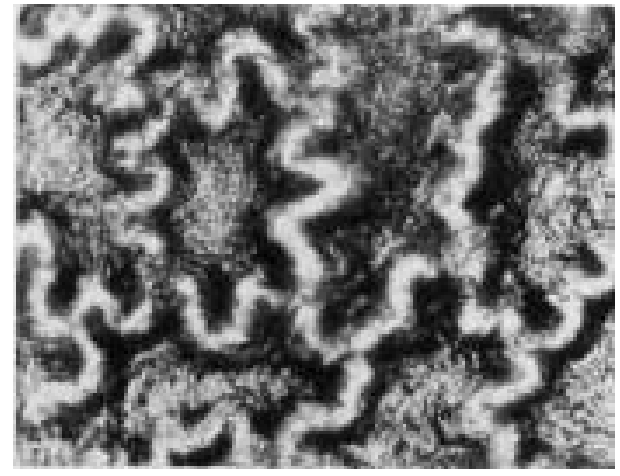

a

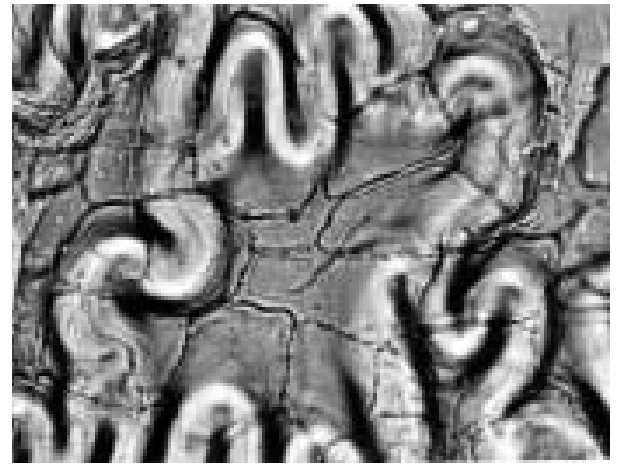

b

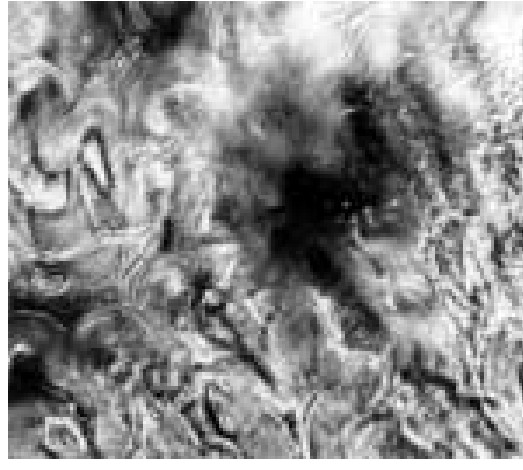

c

Fig. 3. Photomicrographs of slide at 400x magnification of Lycium chilense seeds prepared from feces of Eligmodontia typus (a) compared to reference slides prepared with the sodium bicarbonate method $(b)$ and the Jeffrey's method (c).

reference slides prepared with the sodium bicarbonate method (Fig. 4a) were more distinct than slides prepared with the Jeffrey's method (Fig. 4b).

The proposed technique has several advantages. It is a simple process for preparing reference slides of seed that does not require expensive or dangerous chemical compounds. Because the sodium

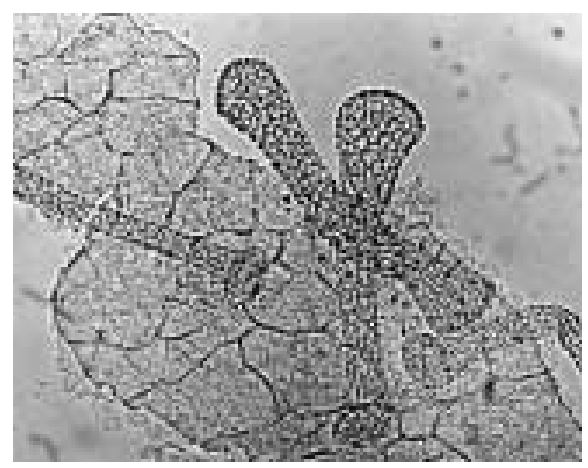

a

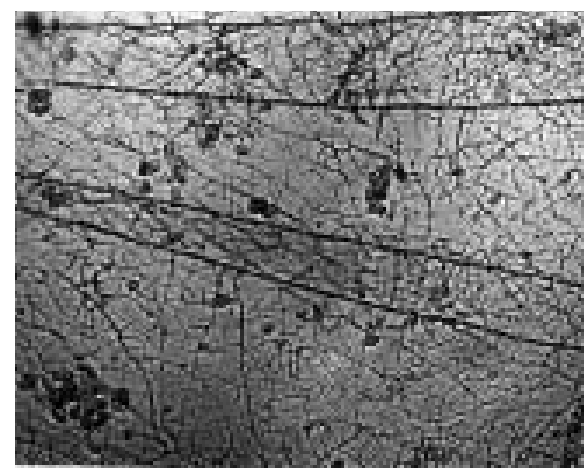

b

Fig. 4. Photomicrographs of reference slides at 200x magnification of Bulnesia retama seeds with trichomes prepared with the sodium bicarbonate method (a) and the Jeffrey's method (b). bicarbonate solution does not deteriorate plant tissues, the material may remain at least 4 months in the maceration solution before the reference slides are prepared (Dacar personal observation). In addition, this technique permits separation of seed coat layers, making it possible to identify not only the plant species but also the seed parts consumed, including starches. The sodium bicarbonate solution can be used in fresh and fossil feces and provides improved identification of epidermal tissues under the microscope (Dacar personal observation). Reference slides can be prepared from herbarium material, which is hydrated after being soaked in the sodium bicarbonate solution (Unpublished data, Dacar). In conclusion, the technique proposed allows for an easier and better preparation of reference slides of hard tissues, such as seed, which usually need elaborate maceration techniques.

\section{Literature Cited}

Burkart, A. 1952. Las leguminosas argentinas, silvestres y cultivadas. Acme Agency, Buenos Aires.

Campos, C.M. 1997. Utilización de recursos alimenticios por mamíferos medianos y pequeños del desierto del Monte, Tesis Doctoral, Univ. Nac. Córdoba.

Castellarini, F., H.L. Agnelli, and J.J. Polop. 1998. Study on the diet and feeding preferences of Calomys venustus (Rodentia, Muridae). Mastozoologia Neotropical. 5:5-11.

Costa, G. 1995. Behavioural adaptations of desert animals. Springer-Verlag, Berlín.

Dellafiore, C. and J.J. Polop. 1994. Feeding habits of Calomys musculinus in the crop fields and its borders. Mastozoologia Neotropical 1:45-50.

Dusi, J.L. 1949. Methods for the determination of food habits by plants microtechniques and histology and their application to cottontail rabbit food habits. J. Wild. Manage. 13:295-298.

Hansen, R.M. 1975. Foods of the hoary marmot on Kenai Peninsula, Alaska. American Mid. Nat., 94:348-353.

Johansen, D.A. 1940. Plant microtechnique. McGraw-Hill Book Co., New York, N.Y.

Krebs, C.J. 1989. Ecological methodology. Harper Collins Pub., New York, N.Y.

Merrill, E.H. 1994. Summer foraging ecology of wapiti (Cervus elaphus roosevelti) in the Mount. St. Helens blast zone. Can. J. Zool. 72:303-311.

Meserve, P.L. 1981. Trophic relationships among small mammals in a Chilean semiarid thorn scrub community. J. Mamm. 62:304-314.

Neal, B. R., D. A. Pulkinen, and B.D. Owen. 1973. A comparison of feacal and stomach contents analysis in the meadow vole (Microtus pennsylvanicus). Can. J. Zool. 51:715-721.

Ojeda, R. A., J. M. Gonnet, C.E. Borghi, S.M. Giannoni, C. Campos, and G.B. Diaz. 1996. Ecological observations of the red vizcacha rat, Tympanoctomys barrerae, in desert habitats of Argentina. Mastozoología Neotropical 3:183-191.

Peralta, I.E. and B.E. Rossi. 1997. Guía para el reconocimiento de especies del banco de semillas de la Reserva de Biosfera de Ñacuñan (Mendoza, Argentina). Boletín de Extensión Científica (IADIZA), Pub. 3. Mendoza.

Reichman, O.J. 1975. Relation of desert rodent diets to available resources. J. Mamm. 56:731-751.

Reynolds, H.G. 1958. Ecology of Merriam`s kangaroo rat on the grazing lands of southern Arizona. Ecol. Monograph. 28:111--127.

Williams, O.B. 1969. An improved technique for identification of plant fragments in herbivore feces. J. Range Manage. 22:51-52. 